\title{
STUDI KELAYAKAN PEMBANGKIT LISTRIK TENAGA MINI HIDRO DI SUNGAI MANULA KECATAMAN PUGUNG KABUPATEN PESISIR BARAT LAMPUNG
}

\author{
Rosnita Rauf*), Helny Lalan, and Budiman \\ Jurusan Teknik Elektro, Fakultas Teknik \& Perencanaan, Universitas Ekasakti \\ J1. Veteran Dalam No. 26 B, Padang \\ *)E-mail : ekasakti5974@gmail.com
}

\begin{abstract}
Abstrak
Pertambahan permintaan kecukupan penyediaan pembangkit listrik semakin meningkat seiring dengan bertambahnya penduduk. Sumber energi yang digunakan saat ini adalah berasal dari PT. PLN Persero. Untuk membangkitkan listrik hingga saat ini masih didominasi oleh bahan bakar fosil, yang merupakan sumber energi yang tidak dapat diperbaharui dan tidak ramah lingkungan. Pembangkit Listrik Mini Hidro merupakan sumber energi terbarukan dan ramah lingkungan yang memiliki potensi untuk menggantikan bahan bakar fosil. Pada penelitian ini dibuat studi kelayakan pembangkit listrik tenaga mini hidro yang berlokasi di Kabupaten Pesisir Barat Lampung. Studi kelayakan ini, yang perlu kita ukur adalah banyaknya debit air andalan yang terdapat di salah satu sungai Taman Nasional Bukit Barisan Selatan (TNBBS) . Hasil penelitian menunjukkan bahwa debit air sungai Manula adalah $\mathrm{Q}=$ 20,32 $\mathrm{m}^{3} /$ dtk dan Beda tinggi atau Head = 98 meter mampu membangkitkan daya minimal sebesar 17,97 MW. Dari hasil daya yang dapat dibangkitkan, berarti pembangkit listrik tenaga mini hidro layak untuk direalisasikan, tetapi perlu adanya kajian secara finansial lebih lanjut.
\end{abstract}

Kata Kunci: Studi Kelayakan, Energi Terbarukan, Pembangkit Listrik Tenaga Mini Hidro (PLTM)

\section{I . PENDAHULUAN}

\subsection{Latar Belakang}

Menipisnya bahan bakar fosil dan peningkatan efek rumah kaca telah menjadi isu krusial yang harus ditangani secara global. Hal ini memicu banyak hal seperti penelitian dan pengembangan besar-besaran terhadap sumber energi alternatif ramah lingkungan beserta pilot plan penyaluran energi yang efisien.

Saat ini negara kita berada dalam kondisi krisis energi karena adanya kenaikan harga BBM di pasaran dunia sehingga menyebabkan kenaikan harga BBM di dalam negeri, akibatnya Pemerintah dalam mengatasi krisis tersebut dengan melakukan pengurangan bahkan penghilangan subsidi BBM padahal PLN saat ini dalam memenuhi pembangkit listrik tenaga diesel, khususnya di daerah terpencil. kebutuhan listrik masih menggunakan

$\begin{gathered}\text { Dalam mengantisipasi hal tersebut } \\ \text { menerbitkan }\end{gathered}$
Pemerintah dah $\begin{gathered}\text { mentan } \\ \text { peraturan/kebijakan yang berkaitan dengan }\end{gathered}$
pemanfaatan sumber energi terbarukan melalui
$:$ Perpres 4/2010 tentang Penugasan kepada
1. PLN untuk melakukan Percepatan
Pembangunan Pembangkit Listrik yang
menggunakan Energi Terbarukan, Gas dan
Batubara;
2. Undang-undang nomor 30 tahun 2009
tentang ketenagalistrikan;
3. Peraturan Menteri Energi dan Sumber
Daya Mineral No. 14/2012 tentang
Manajemen Energi Tenaga Listrik Oleh PT
PLN dari Pembangkit Tenaga Listrik yang
Menggunakan Energi Terbarukan Skala
Kecil dan Menengah.
4. Peraturan Menteri Energi dan Sumber
Daya Mineral No. 12/2014 tentang Harga
Pembelian Tenaga Listrik Oleh PT PLN dari
Pembangkit Tenaga Listrik yang
menggunakan Energi Terbarukan Skala Kecil
dan Menengah.

$\begin{array}{ccr}\text { Dalam } & \text { mengantisipasi } & \text { hal tersebut } \\ \text { Pemerintah } & \text { sudah } & \text { menerbitkan }\end{array}$ peraturan/kebijakan yang berkaitan dengan pemanfaatan sumber energi terbarukan melalui

1. Perpres $4 / 2010$ tentang Penugasan kepada PLN untuk melakukan Percepatan Pembangunan Pembangkit Listrik yang menggunakan Energi Terbarukan, Gas dan Batubara;

2. Undang-undang nomor 30 tahun 2009 tentang ketenagalistrikan;

3. Peraturan Menteri Energi dan Sumber Daya Mineral No. 14/2012 tentang Manajemen Energi Tenaga Listrik Oleh PT PLN dari Pembangkit Tenaga Listrik yang Menggunakan Energi Terbarukan Skala

[Type text] 
Peraturan Menteri ini memberikan dorongan kepada pengembang swasta untuk membangun pembangkit listrik dari energi terbarukan.

Dengan adanya ketentuan pemerintah yang membuka peluang usaha dibidang energi kelistrikan yang hasilnya harus diserap oleh PLN untuk disalurkan ke konsumen, maka peluang ini membuka para investor swasta untuk

\begin{tabular}{|l|l|l|l|l|l|l|}
\hline $\mathrm{B} / \mathrm{H}$ & $5^{\prime}$ & $10^{\prime}$ & $15^{\prime}$ & $20^{\prime}$ & $30^{\prime}$ & $40^{\prime}$ \\
\hline $\mathrm{Vm} / \mathrm{Vs}$ & 0,98 & 0,95 & 0,92 & 0,90 & 0,87 & 0,85 \\
\hline
\end{tabular}

mulai mempelajari potensi energi tenaga air. Salah satunya ada pada daerah kabupaten Pesisir Barat Lampung yang dibuat dalam Studi Kelayakan PLTM di Pugung Kabupaten Pesisir Barat.

\subsection{Lingkup Pekerjaan}

Lingkup pekerjaan studi kelayakan ini ada 3 tahap keseluruhan studi kelayakan dan desain rinci. Beberapa kegiatan tahapan tersebut berupa lapangan dan analisa, yaitu :

\subsubsection{Pekerjaan Pengukuran Debit Sesaat}

Pekerjaan debit sesaat adalah pekerjaan pengukuran debit pada saat ke lokasi potensi sungai pada daerah bangunan-bangunan utama PLTM, meliputi ukuran/skala yang diminta adalah sebagai berikut:

a. Pengukuran secara langsung

b. Pengukuran secara tidak langsung

Pada pengukuran secara tidak langsung, ada beberapa metode, diantaranya :

\section{Pelampung}

Terdapat dua tipe pelampung yang digunakan yaitu: (i) pelampung permukaan, dan (ii) pelampung tangkai. Tipe pelampung tangkai lebih teliti dibandingkan tipe pelampung permukaan. Pada permukaan debit dengan pelampung dipilih bagian sungai yang lurus dan seragam, kondisi aliran seragam dengan pergolakannya seminim mungkin. Pengukuran dilakukan pada saat tidak ada angin. Pada bentang terpilih (jarak tergantung pada kecepatan aliran, waktu yang ditempuh pelampung untuk jarak tersebut tidak boleh lebih dari 20 detik) paling sedikit lebih panjang dibanding lebar aliran. Kecepatan aliran permukaan ditentukan berdasarkan rata - rata yang diperlukan pelampung menempuh jarak tersebut. Sedang kecepatan rata - rata didekati dengan pengukuran kecepatan permukaan dengan suatu koefisien yang besarnya tergantung dari perbandingan antara lebar dan kedalaman air. Koefisien kecepatan pengaliran dari pelampung permukaan sebagai berikut:

\section{Keterangan:}

$$
\begin{array}{ll}
\mathrm{B} & =\text { lebar permukaan aliran } \\
\mathrm{H} & =\text { kedalaman air } \\
\mathrm{Vm} & =\text { kecepatan rata }- \text { rata } \\
\mathrm{Vs}= & \text { kecepatan pada permukaan }
\end{array}
$$

Dalam pelepasan pelampung harus diingat bahwa pada waktu pelepasannya, pelampung tidak stabil oleh karena itu perhitungan kecepatan tidak dapat dilakukan pada saat pelampung baru dilepaskan, keadaan stabil akan dicapai 5 detik sesudah pelepasannya. Pada keadaan pelampung stabil baru dapat dimulai pengukuran kecepatannya.

Debit aliran diperhitungkan berdasarkan kecepatan rata - rata kali luas penampang. Pada pengukuran dengan pelampung, dibutuhkan paling sedikit 2 penampang melintang. Dari 2 pengukuran penampang melintang ini dicari penampang melintang rata - ratanya, dengan jangka garis tengah lebar permukaan air kedua penampang melintang yang diukur pada waktu bersama

- sama disusun berimpitan, penampang lintang rata-rata didapat dengan menentukan titik - titik pertengahan garis - garis horizontal dan vertikal dari penampang itu, jika terdapat tiga penampang melintang, maka mula - mula dibuat penampang melintang rata - rata antara penampang melintang rata - rata yang diperoleh dari penampang lintang teratas dan terbawah.

Debit aliran kecepatan rata - rata:

$$
\mathbf{Q}=\mathrm{C} \cdot \mathbf{V p} \text { Ap }
$$

Keterangan: 
$\mathrm{Q}=$ debit aliran

$\mathrm{C}=$ koefisien yang digunakan

$\mathrm{Vp}=$ kecepatan rata - rata pelampung

$\mathrm{Ap}=$ luas aliran rata - rata

2. Pengukuran dengan Current Meter

Alat ini terdiri dari flow detecting unit dan counter unit. Aliran yang diterima detecting unit akan terbaca pada counter unit, yang terbaca pada counter unit dapat merupakan jumlah putaran dari propeller maupun langsung menunjukkan kecepatan aliran, aliran dihitung terlebih dahulu dengan memasukkan dalam rumus yang sudah dibuat oleh pembuat alat untuk tiap - tiap propeller. Pada jenis yang menunjukkan langsung, kecepatan aliran yang sebenarnya diperoleh dengan mengalihkan factor koreksi yang dilengkapi pada masing-masing alat bersangkutan. Propeler pada detecting unit dapat berupa : mangkok, bilah dan sekrup. Bentuk dan ukuran propeler ini berkaitan dengan besar kecilnya aliran yang diukur.

Debit aliran dihitung dari rumus :

$$
\begin{aligned}
& \mathbf{Q}=\mathbf{V} \times \mathbf{A} \\
& \text { dimana : } \\
& \mathrm{V}=\text { Kecepatang aliran } \\
& \mathrm{A}=\text { Luas penampang }
\end{aligned}
$$

Dengan demikian dalam pengukuran tersebut disamping harus mengukur kecepatan aliran, diukur pula luas penampangnya. Distribusi kecepatan untuk tiap bagian pada saluran tidak sama, distribusi kecepatan tergantung pada :

$>$ Bentuk saluran

Kekasaran saluran dan

Kondisi kelurusan saluran

Dalam penggunaan current meter pengetahuan mengenai distribusi kecepatan ini amat penting. Hal ini bertalian dengan penentuan kecepatan aliran yang dapat dianggap mewakili rata-rata kecepatan pada bidang tersebut. Dari hasil penelitian "United Stated Geological Survey" aliran air di saluran (stream) dan sungai mempunyai karakteristik distribusi kecepatan sebagai berikut: a. Kurva distribusi kecepatan pada penampang melintang berbentuk parabolic.

b. Lokasi kecepatan maksimum berada antara 0,05 s/d 0,25 h kedalam air dihitung dari permukaan aliran.

c. Kecepatan rata-rata berada $\pm 0,6$ kedalaman dibawah permukaan air. d. Kecepatan rata-rata $\pm 85 \%$ kecepatan permukaan.

e. Untuk memperoleh ketelitian yang lebih besar dilakukan pengukuran secara mendetail kearah vertical dengan menggunakan integrasi dari pengukuran tersebut dapat dihitung kecepatan rataratanya. Dalam pelaksanaan kecepatan rata-rata nya.

Pengukuran luas penampang aliran dilakukan dengan membuat profil penampang melintangnya dengan cara mengadakan pengukuran kearah horizontal (lebar aliran) dan ke arah vertical (kedalamam aliran). Luas aliran merupakan jumlah luas tiap bagian (segmen) dari profil yang terbuat pada tiap bagian tersebut di ukur kecepatan alirannya.

Debit aliran di segmen $=(\mathrm{Qi})=\mathrm{Ai} \times \mathrm{Vi}$ Keterangan :

Qi : Debit aliran segmen i

Ai : Luas aliran pada segmen i

Vi : Kecepatan aliran pada segmen i

\subsubsection{Pekerjaan Pengukuran dan analisa} Head

Pengukuran Tinggi terjun dapat dilakukan dengan berbagai cara, antara lain :

1. Menggunakan theodolite atau waterpass untuk dapat mengetahui beda tinggi.

2. Menggunakan peralatan sederhana, yaitu selang berisi air diameter $1 / 2$ $\mathrm{cm}$, tongkat pengukur dan rol meter, pengukuran dilakukan secara bertahap, hal ini dapat dilihat pada gambar di bawah ini : 


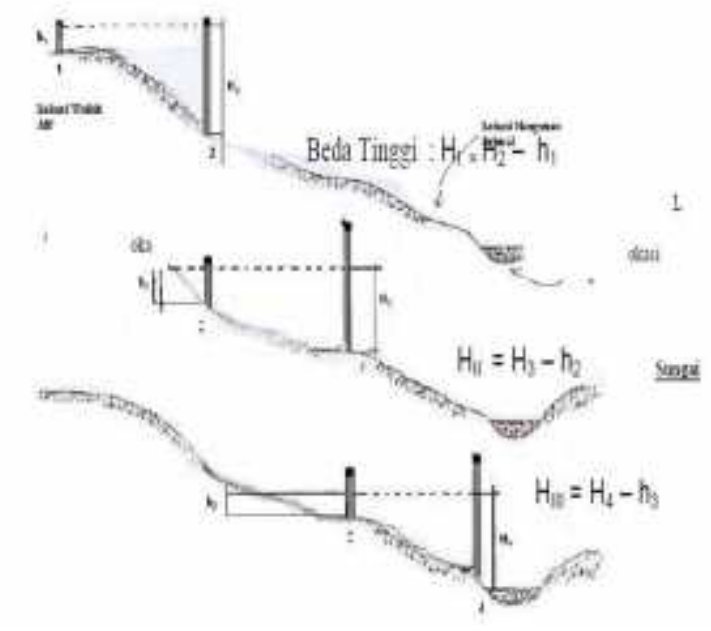

Gambar 1.1 Mengukur Tinggi Terjun.

Selanjutnya rata-rata tinggi total, dihitung dengan rumus :

$\mathrm{H}$ Total $=\mathrm{H} 1+\mathrm{H} 2+\mathrm{H} 3(\mathrm{~m})$

Teori di atas merupakan data hasil survei Teknis yang dikelompokan dan dimasukan dalam data isian, meliputi :

Kelompok data Isian Teknis meliputi :

a. Data ini mengutarakan tentang kondisi dan situasi jalan menuju desa sasaran, bentuk pemukiman, sistim pengairan desa.

b. Data tentang potensi air dan kondisi sungai. Data isian ini merupakan hasil survei potensi air, yang berisikan data lebar sungai, tinggi dasar, tinggi air, kecepatran air, luas penampang basah, debit rata-rata dan daya yang dapat dihasilkan.

c. Jarak jaringan listrik PLN dengan lokasi sasaran. Data ini tentang jarak jaringan listrik, dan nama desa terdekat dengan lokasi yang telah mendapat sambungan listrik PLN.

Pada prinsipnya, ketinggian antara titik intake dan bak penenang dan ketinggian antara bak penenang dan titik keluar air harus diukur. Pada awal tahap perencanaan, bagaimanapun, adalah mungkin cukup untuk mengukur ketinggian antara lokasi bak penenang yang direncanakan dan level keluaran/buangan air.

\section{BAB II STUDI IDENTIFIKASI WILAYAH} 2.1. Profil Propinsi Lampung

[Type text]
Di Pulau Sumatera terdapat 8 Propinsi, yaitu D.I. Aceh, Sumatera Utara, Sumatera Barat, Bengkulu, Riau, Sumatera Selatan, Jambi, dan Lampung. Secara geografis, Propinsi Lampung terletak pada posisi $3^{\circ} 45^{\prime} \mathrm{LS}-6^{\mathrm{O}} 45^{\prime}$ LS dan $103^{\circ} 40^{\prime}$ BT $-105^{\circ} 50^{\prime}$ BT. Luas Propinsi Lampung meliputi areal dataran sekitar $35.376 \mathrm{~km}^{2}$ termasuk pulau-pulau. Lampung terletak pada bagian sebelah paling ujung tenggara Pulau Sumatera, yang berbatasan dengan :

a. Sebelah utara berbatasan dengan Propinsi Sumatera Selatan dan Propinsi Bengkulu,

b. Sebelah selatan berbatasan dengan Selat Sunda,

c. Sebelah timur berbatasan dengan Laut Jawa,

d. Sebelah barat berbatasan dengan Samudra Hindia

Daerah Propinsi Lampung ditetapkan sèbágai propinsi berdasarkan UndangUndang No.14 tahun 1964. Sebelumnya merupakan karesidenan yang termasuk dalam wilayah Propinsi Sumatera Selatan.

Keadaan alam daerah Lampung dapat dijelaskan sebagai berikut: sebelah barat dan selatan, di sepanjang pantai, merupakan daerah yang berbukit-bukit sebagai sambungan dari jalur pegunungan Bukit Barisan. Di tengah-tengah merupakan dataran rendah, sedangkan ke dekat pantai di sebelah timur, di sepanjang tepi Laut Jawa terus ke utara, merupakan daerah rawa-rawa perairan yang luas (Gambar-1).

Ibukota Propinsi Lampung adalah

Bandar Lampung, yang merupakan gabungan dari kota kembar TanjungkarangTelukbetung, yang oleh karena pesatnya perkembangan, sekarang telah menjadi satu kota yang luas. Kotamadya Bandar Lampung merupakan pusat kegiatan pemerintahan, sosial, politik, pendidikan dan kebudayaan, serta pusat kegiatan perekonomian Propinsi Lampung. Lampung dibagi dalam 8 Kabupaten dan 2 Kotamadya. Dari 10 daerah Kabupaten/ Kota tersebut, 6 daerah Kabupaten/Kota di antaranya memiliki wilayah pesisir. Daerah

Kabupaten/Kota yang memiliki wilayah pesisir adalah Kabupaten Lampung Barat, 
Kabupaten Tanggamus, Kabupaten Lampung

Selatan, Kotamadya Bandar Lampung,

Kabupaten Lampung Timur, dan Kabupaten

Tulang Bawang, sedangkan yang tidak memiliki wilayah pesisir adalah Kotamadya

Metro, Kabupaten Lampung Tengah,

Kabupaten Way Kanan, dan Kabupaten

Lampung Utara.

\subsection{Kabupaten Pesisir Barat}

\subsubsection{Geografis, Administratif dan Kondisi Fisik}

Kabupaten Pesisir Barat dengan ibukota Krui adalah salah satu dari Lima belas kabupaten/kota di wilayah Provinsi Lampung. Kabupaten ini dibentuk berdasarkan UndangUndang No. 22 Tahun 2012 (Lembaran Negara Nomor 231, Tambahan Lembaran Negara Nomor 5364) tentang Pembentukan Daerah Otonomi Baru (DOB) Kabupaten Pesisir Barat Provinsi Lampung tertanggal 16 November 2012 dan diundangkan pada tanggal 17

November 2012, dengan batas :

a. Sebelah utara berbatasan dengan Desa Ujung Rembun, Desa Pancur Mas, Desa Sukabanjar Kecamatan Lumbok Seminung, Desa Kubu Prahu Kecamatan BalikBukit, Desa Kutabesi, Desa Sukabumi Kecamatan Batu Brak, Desa Sukamarga, Desa Ringinsari, Desa Sumber Agung, Desa Tuguratu, Desa Banding Agung Kecamatan Suoh, Desa Hantatai, Desa Tembelang, Desa Gunung Ratu Kecamatan Bandar Negeri Suoh Kabupaten Lampung Barat, Desa Gunung Doh Kecamatan Bandar Negeri Semuong, Desa Ngarit, Desa Rejosari, Desa Petekayu, Desa Sirnagalih Kecamatan Ulu Belu, Desa Datar Lebuay Kecamatan Naningan Kabupaten Pesisir Barat, Desa Way Beluah, dan Desa Melaya Kecamatan Banding Agung Kabupaten Ogan Komering Ulu Selatan Provinsi Sumatera Selatan;

b. Sebelah timur berbatasan dengan Desa Tampang Tua Kecamatan Pematang Sawa, Desa Sedayu, Desa Sidomulyo Kecamatan Semaka Kabupaten Pesisir Barat; c. Sebelah selatan berbatasan dengan Samudera Hindia; dan

d. Sebelah barat berbatasan dengan Desa Tebing Rambutan Kecamatan Nasal Kabupaten Kaur Provinsi Bengkulu.

Wilayah Kabupaten Pesisir Barat memiliki luas $\pm 2.907,23 \mathrm{Km} 2$ atau 8,39\% dari Luas Wilayah Provinsi Lampung, dengan mata pencaharian pokok sebagian besar penduduknya sebagai petani dan nelayan. Secara geografis letak Kabupaten Pesisir Barat pada koordinat : $4^{\circ}, 40^{\prime}, 0^{\prime \prime}-6^{\circ}, 0^{\prime}, 0^{\prime \prime}$ Lintang Selatan dan $103^{\circ}, 30^{\prime}, 0^{\prime \prime}-104^{\circ}, 50^{\prime}$, 0 " Bujur Timur.

\subsubsection{Kawasan Konservasi}

Propinsi Lampung dengan luas daratan 3,5 juta ha memiliki 1,237 juta ha kawasan hutan dan yang telah ditetapkan sebagai kawasan konservasi seluas 422.500 ha $(12,8 \%)$. Selain kawasan konservasi hutan, Lampung memiliki kawasan konservasi laut, kepulauan, dan beberapa lokasi yang diusulkan sebagai taman buru, suaka marga satwa, dan cagar alam rawa air tawar sebagai habitat berbagai jenis burung air.

Berdasarkan letaknya, kawasankawasan konservasi tersebut, sebagian arealnya meliputi wilayah pesisir dan berbatasan langsung dengan laut seperti Taman Nasional dan Cagar Alam Laut Bukit Barisan Selatan di Pantai Barat dan TN. Way Kambas di Pantai Timur. Di Selat Sunda terdapat Cagar Alam Laut Gugus Kepulauan Krakatau.

Pulau Sumatera lebih kaya akan keanekaragaman jenis tumbuhannya dengan pulau lainnya di Indonesia. Di Sumatera terdapat 17 marga endemik dan didukung oleh berbagai macam tipe vegetasi seperti hutan mangrove, hutan rawa dan pantai, hutan dataran rendah, dan hutan pegunungan.

Ditinjau dari keanekaragaman fauna, di Sumatera terdapat 196 jenis mamalia, 20 endemik, 15 jenis yang hanya dijumpai di Indonesia dan 22 jenis hewan mamalia Asia yang tidak terdapat di daerah lainnya di Indonesia. Dari 580 jenis burung, terdapat 
14 jenis yang endemik dan sekitar 120 jenis burung yang bermigrasi.

\subsubsection{Hidrologi}

Wilayah Lampung Barat di bagian barat mempunyai sungai-sungai yang mengalir pendek dengan pola aliran dendritik yang menyebabkan daerah ini ditandai dengan jarangnya banjir sebab pada saat musim hujan datang bersamaan air tidak terkonsentrasi dan timing lagnya menjadi lambat. Delta marine ditandai dengan agregat kasar hasil endapan aluvial vulkanik, hal ini menyebabkan bila air besar muara sungai sering berpindah (meander). Sungai sungai yang berukuran pendek dan mengalir di lereng terjal seperti ini sukar dikembangkan untuk irigasi, kecuali yang sudah mengalir di daerah delta pantai, umumnya mudah dikembangkan walaupun masih terkena pengaruh pasang surut laut. Pada bagian timur wilayah Lampung Barat merupakan daerah tangkapan air (catchment area) sungai-sungai besar yang mengalir ke arah timur antara lain : Way Besai, Way Seputih dan sebagainya.

Dengan berkurangnya flora penutup tanah dan sifat drainase tanah yang baik (terdiri dari lempung pesiran bergeluh) praktis daya simpan air daerah ini sangat kecil, ini menyebabkan fluktuasi aliran permukaan (run off) makin besar, sungaisungai yang mengalir ke sebelah timur menjadi terganggu kestabilannya. Umumnya sungai - sungai yang mengalir ke sebelah barat masih stabil karena didukung oleh banyaknya flora penutup tanah dan belum terganggunya air tanah dangkal sebagai sumber mata air.

Gambar 2.3. Peta Daerah Aliran Sungai di Wilayah Kabupaten Pesisir Barat

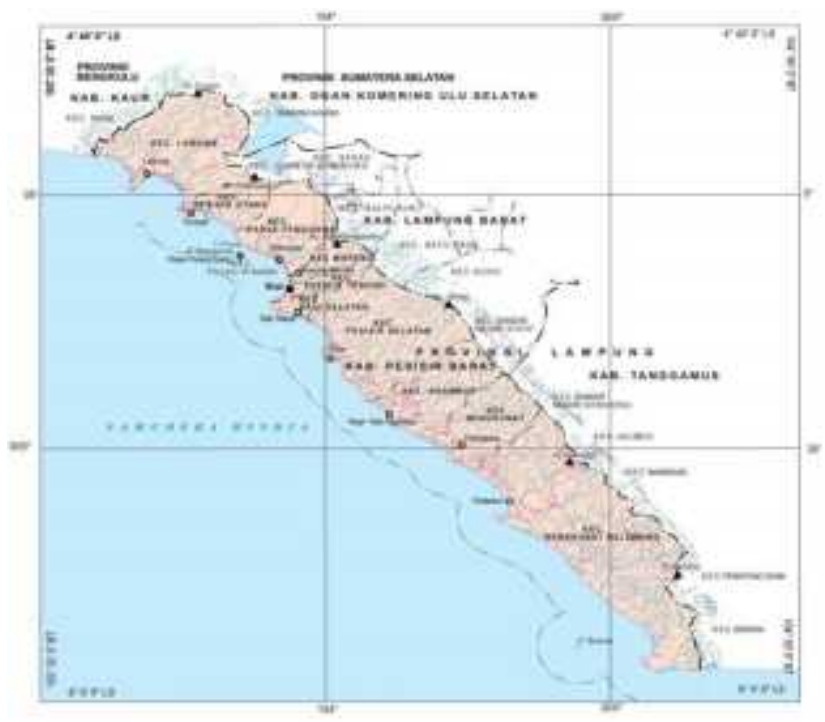

\subsection{Akses dan Tracking Lokasi}

Survey yang dilakukan dapat dilihat pada gambar 2.4.

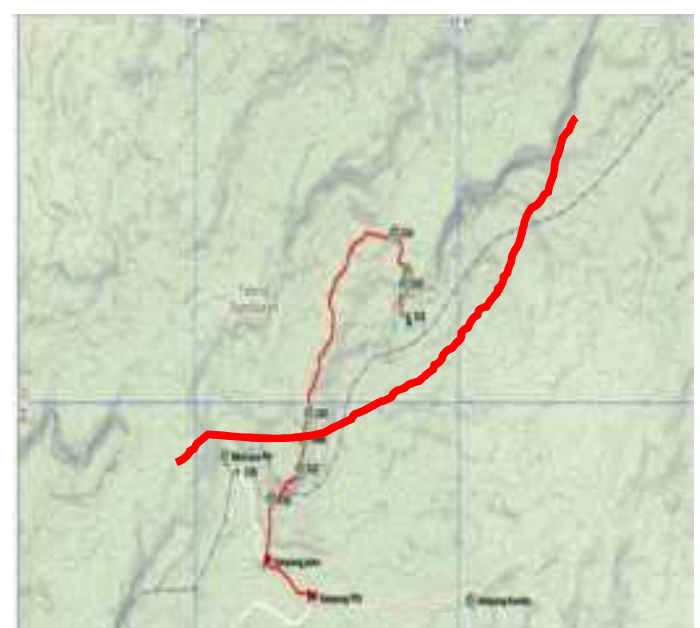

Gambar 2.4. Tracking Perencanaan Mini Hidro Pugung

Tracking yang ditandai dengan garis merah merupakan jalan setapak di menuju sungai, dimana jarak dari bendung ke power house $\pm 5,2 \mathrm{~km}$. Sedangkan jarak perjalanan dari simpang jalan raya yaitu simpang PDI , hanya $1 \mathrm{~km}$. Untuk water way berjarak $\pm 2,5 \mathrm{~km}$. Untuk titik koordinat masing-masingnya :

1. Bendung S4 5129.1 E103 3935.7

2. Forebay S4 5211.8 E103 3818.5

3. Power House S4 52 07.7 E103 3813.0 


\subsection{Catchman Area}

Catchment area merupakan daerah tangkapan air yang bisa melakukan penangkapan dan penyerapan air hujan yang kemudian secara siklus akan dialirkan kembali ke sungai. Catchment area penting untuk diperhatikangkan karena kondisi hutan, lingkungan dan serapan air di area ini bisa mempengaruhi kontinuitas produksi energi listrik. Jika catchment area tidak terjaga dengan baik maka besar kemungkinan suatu saat terjadi kerusakan lingkungan yang menyebabkan tidak stabilnya aliran air sungai sepanjang tahun yang mengakibatkan terganggunya proses produksi energi.

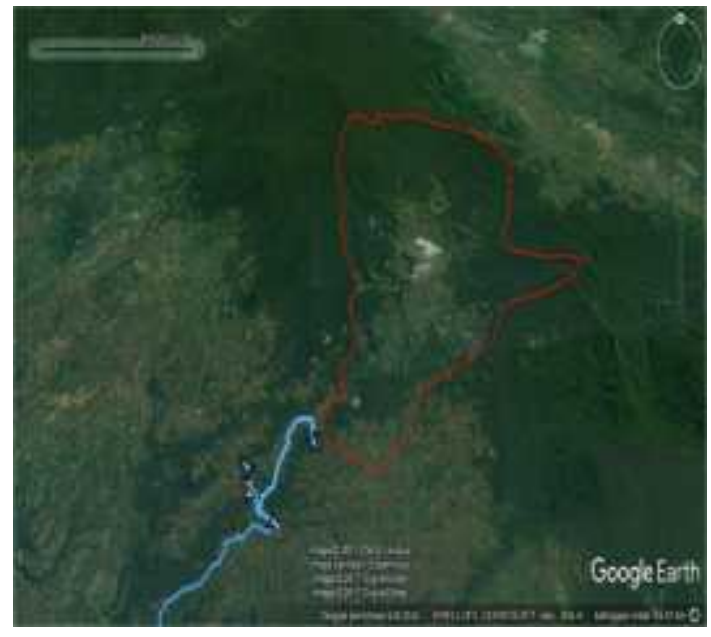

Gambar 2.6. Catchment area mini hidro Pugung

Bila dilihat dari google earth maka $100 \%$ wilayah cacthment area merupakan hutan lindung TNBBS (Taman Nasional Bukit Barisan Selatan), hal ini menguntungkan karena mengurangi biaya konservasi hutan dan penjagaan lingkungan karena sudah di handle oleh pemerintah dan dinas kehutanan sepenuhnya. Sungai yang dimanfaatkan dan catchment areanya dapat diperlihatkan pada gambar 2.6. Diperhitungkan luas catchment area kurang lebih $160,97 \mathrm{~km}^{2}$. Bila rata-rata curah hujan Kabupaten Lampung Barat 2.500 - $3000 \mathrm{~mm} /$ tahun, maka diperkirakan debit ratarata sangat besar dan kontinuitas air dapat terpenuhi.

\section{BAB III HASIL PENGUKURAN}

\subsection{Latar Belakang}

Studi kelayakan sumber energi hidro adalah penelitian ketersediaan potensi sumber energi hidro untuk pembangkit listrik tenaga minihidro dan kondisi lokasi beserta datadata pendukung. Studi ini digunakan untuk memilih dan mengutamakan lokasi untuk struktur bangunan dan luaran (output) dari pembangkit. Studi meliputi kegiatan observasi, pengumpulan data, dan pengumpulan informasi lokasi daerah aliran sungai yang memiliki potensi sumber energi hidro. Hasil studi kelayakan ini membutuhkan studi yang lebih rinci, teliti, dan membutuhkan biaya lebih besar.

\subsection{Pekerjaan Hidrologi}

Pekerjaan studi hidrologi pada tahap awal hanya dilakukan pengukuran debit sesaat, dimana kita melakukan pengukuran dengan current meter. Pekerjaan ini akan mencakup :

$\phi \quad$ Pengukuran penampang sungai

$\phi$ Pemasangan staff gauge

$\phi$ Pengukuran debit sesaat dengan peralatan current meter/pelampung

Penampang sungai diukur dengan meteran panjang $50 \mathrm{~m}$. Ujung meteran diletakkan di salah satu tepi sungai dan meteran ditarik ke ujung lain. Setiap jarak $1 \mathrm{~m}$ diukur kedalaman air dari permukaan. Pada pengukuran ini diperoleh lebar penampang sungai 15 sampai $40 \mathrm{~m}^{2}$ dan lebar basah 12,6 meter, dengan kedalaman maksimum $1.4 \mathrm{~m}$. Kecepatan maksimum dari current meter adalah 1,4 $\mathrm{m} /$ detik. Hasil pengukuran penampang sungai digambarkan sebagai berikut: 


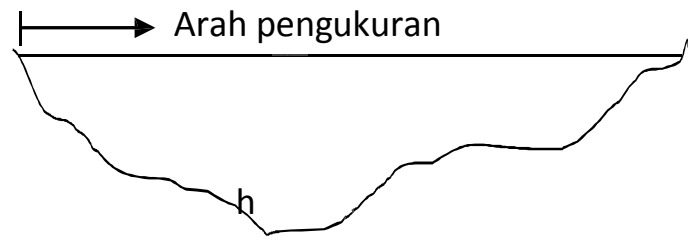

Gambar 3.1. Ilustrasi pengukuran penampang sungai

Tabel 1. Hasil pengukuran potensi sungai

\begin{tabular}{|c|c|c|}
\hline Titik & $\mathrm{H}(\mathrm{m})$ & Vol $(\mathrm{m} 3 / \mathrm{dt})$ \\
\hline 1 & 1.1 & 1 \\
2 & 1.22 & 1.2 \\
3 & 1.3 & 1.2 \\
\hline 4 & $1.3 \mathfrak{y} x$ & 1.3 \\
\hline 5 & 1.22 & 1.1 \\
\hline 6 & 1.3 & 1.4 \\
\hline 7 & 1.3 & 1.3 \\
\hline 8 & 1.4 & 1.4 \\
\hline 9 & 1.4 & 1.4 \\
\hline Jumlah & 11.54 & 11.3 \\
\hline Mean & 1.28 & 1.26 \\
\hline
\end{tabular}

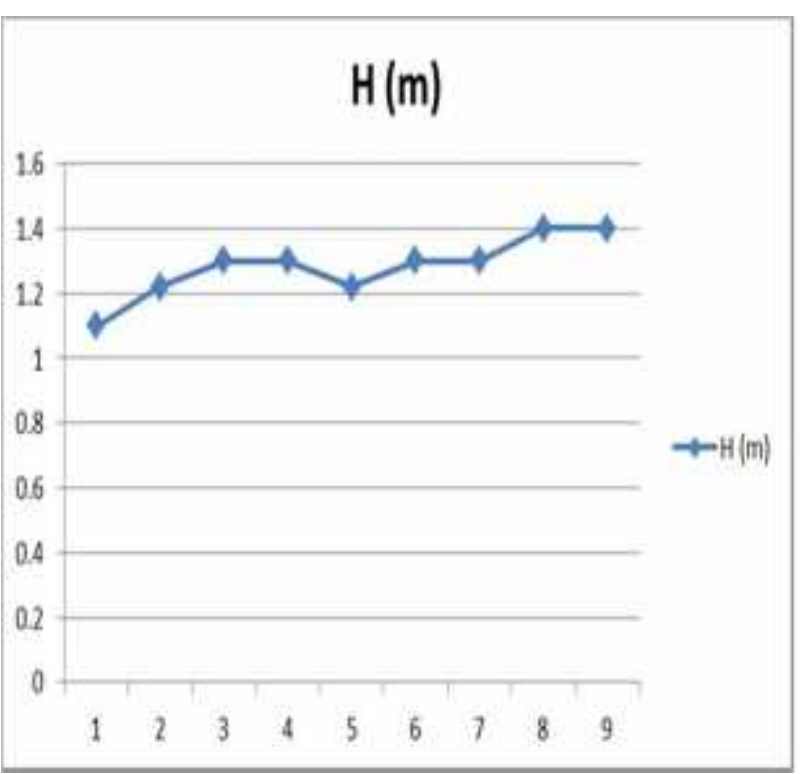

Gambar 3.2. Pengukuran profil melintang sungai

Dari data diatas, dimana lebar sungai $1=12,6$ meter dan kedalaman rata-rata sungai didapat $\mathrm{d}=1,28$ meter, maka didapat lebar penampang sungai $(\mathrm{A})$, dimana :

$$
A=d l x
$$

[Type text] maka lebar penampang sungai $\mathrm{A}=16,128$ $\mathrm{m}^{2}$, dengan penampang tersebut didapat debit air (Q) dimana $Q=V \times A\left(\mathrm{~m}^{3} / \mathrm{dtk}\right)$, dan didapatkan debit dengan kecepatan rata-rata 1,26 $\mathrm{m} / \mathrm{dt}$ adalah $20,32 \mathrm{~m}^{3} / \mathrm{dtk}$.

\subsection{Kelayakan Potensi}

Berdasarkan pada hasil analisa hidrologi dan pengukuran head, daya yang dapat dibangkitkan dapat dihitung menggunakan persamaan berikut:

$$
P=Q \times H \times g
$$

Dimana:

$\mathrm{P}=$ daya yang dihasilkan, $\mathrm{kW}$

$\mathfrak{y}=$ efisiensi dari turbin dan generator,

diasumsikan 0,92

$\mathrm{Q}=$ debit air, dalam $\mathrm{m} 3 /$ detik

$\mathrm{H}=$ Head, (dalam m)

$\mathrm{g}=$ percepatan gravitasi, $(9,81 \mathrm{~m} / \mathrm{s} 2)$

Selanjutnya untuk perkiraan daya yang dapat dihasilkan disajikan pada perhitungan berikut, $P=9,81 \times 20,32 \times 98^{x}$ 0,92 dan didapatkan daya sebesar 17,97 MW.

\subsection{Kesimpulan}

Dari hasil survey lokasi dan perhitungan, maka didapatkan :

1. Lokasi potensi berada pada desa Pugung, kabupaten Lampung Barat

2. Lokasi desa Pugung ini, dinyatakan layak dibangunnya Pembangkit Listrik Tenaga Mini Hidro dengan debit air sesaat $20,32 \mathrm{~m}^{3} /$ dtk dan Head $98 \mathrm{~m}$.

3. Catchment area sangat luas, hal ini sangat mendukung akan ketersediannya air.

4. Dilihat dari peta kawasan Taman Nasional Bukit Barisan Selatan (TNBBS), lokasi rencana PLTM merupakan kawasan zona rimba.

5. Dari simpang jalan raya kawasan TNBBS hingga Power House, berjarak $6,2 \mathrm{~km}$ dengan water way didalamnya \pm $2,5 \mathrm{~km}$. 
6. Untuk daerah kawasan TNBBS saat ini belum ada tiang TM, sampai tiang terakhir Trafo yang ada berjarak $\pm 2,3 \mathrm{~km}$ dan GH berada di Krui berjarak 44,6 km dari batas kawasan TNBBS.

\subsection{Saran}

Untuk keberlanjutan, studi kelayakan ini perlu dilanjutkan yaitu :

1. Zona rimba pada kawasan TNBBS harus di proses dalam perubahan zona pemanfaatan.

2. Studi kelayakan ini dilanjutkan dengan perencanaan dan detail engineering design dari banyak bidang ilmu yang mendukung pembangunan PLTM.

\section{Daftar Pustaka}

1. European Amall Hydropower Association (ESHA). (2004). Guide on How to Development a small Hydropower Plant.

2. GIZ. (t.thn.). Legal Frameworks for Renewable Energy. GIZ.

3. Handini, W. (2010). Studi Implementasi PLTH di Bengkunat, Lampung Utara. FT.UI.

4. S.Chowdhury, \& P.Croesley, S. a. (2009). Microgrids and Active Distribution Networks. London: The Institution of Engineering and Technology.

5. Kadir, A. 1995. Energi: Sumberdaya, Inovasi, Tenaga Listrik, Potensi Ekonomi. Jakarta: Universitas Indonesia

6. Makmun dan Sri Lestari Rahayu. 1995.Permasalahan Bidang Ketenagalistrikan Di Indonesia Sekarang Dan Masa Depan. Jakarta: Fokus Media. 
